\title{
Performance Analysis of EPCO building through Electrical Energy Audit
}

\author{
Surabhi Nigam ${ }^{\dagger}$, Savita Vyas ${ }^{*}$, Anoop Shrivastava ${ }^{\dagger}$ \\ † School of Energy \& Environment Management, Rajiv Gandhi Proudyogiki Vishwavidyalaya, Bhopal, India \\ †Environmental Planning \& Coordination Organisation, Bhopal, India
}

Accepted 27 Sept 2016, Available online 03 Oct 2016, Vol.6, No.5 (Oct 2016)

\begin{abstract}
Net Zero Energy Buildings have a very high potential to transform the ways of energy use in the buildings. The paper covers such transforming measures to be implemented on Environmental Planning \& Coordination Organisation (EPCO), Bhopal, to bring it as a Net Zero Energy Building.
\end{abstract}

Keywords: Net Zero Energy Building, Energy efficient, Energy audit, Energy management.

\section{Introduction}

The shortage of conventional resources such as fossil fuels, increasing greenhouse gas (GHG) emissions resulting in global warming and most importantly increasing energy price has brought into attention the increasing energy consumption rate. Even with substantial advancements in energy efficiency and renewable energy, the energy consumption worldwide is growing at a considerable rate(Torcellini, Pless et al. 2015).

Residential and commercial buildings use about $33 \%$ of total electricity used in India. The residential sector accounts for $24 \%$ while commercial sector accounts for $9 \%$ of total energy used in India.

In the residential sector, electricity consumption for space cooling and thermal comfort using fans and air conditioners is around $45 \%$ of the electricity consumption of this sector, along with $28 \%$ consumption by lighting(Kapoor, Deshmukh et al. 2011).

In the commercial sector, the electricity consumption growth rate is about $12-14 \%$ in recent years. This problem of energy consumption will not disappear by itself thus certain measures are taken across the world(Mukherjee 2011).

Energy Management plays a vital role in such a condition of crisis. Energy management is basically a strategy made to optimize the energy use so as to maximize the profits with least cost and least effect on the environment.

Net Zero Energy is one such initiative taken in order to address this challenge. To control the growth rate of

*Corresponding author Savita Vyas, Supervisor working as Assistant Professor. buildings energy consumption a shift towards net zero energy buildings is needed.Net Zero Energy Buildings are highly efficient buildings with extremely low energy demand, which is met by renewable energy sources.

A building employs following measures to be a net zero energy building:

1. Passive Design

2. HVAC Design

3. Energy Efficient Lighting

4. Energy Efficient Appliances

5. Renewable technologies/ Renewable Energy Systems

A net zero energy building has various advantages:

1. Reduces greenhouse gas emissions that release in the atmosphere.

2. Reduces pollution levels.

3. Reduces energy consumption without sacrificing the comfort levels.

4. Creates, expands and shapes the markets for green products and services.

5. Optimizes economic performance over the building's lifetime(Darko, Nagrath et al. 2013).

\section{Objective}

The main objective of the work is to identify the measures to be taken in order to transform one of the buildings of Environmental Planning \& Coordination Organisation (EPCO) into a net-zero energy building. 
This can be achieved by following the process given below:

1. Comparing the methodologies and design of traditional buildings and net zero energy buildings.

2. Evaluating the economic benefits of net-zero energy building.

3. Determining the potential of renewable sources of energy for power generation in the campus.

\section{Methodology}

The methodology to achieve and maintain the optimum energy and its utilization and minimizing the energy costs consists of the following steps:

1. Energy Audit- Collection of electricity bills to study the load pattern of the building.

2. Documentation of collected data i.e. energy use, costs etc.

3. Selection of the type of Net Zero Energy building.

4. Analysis of building designs and performance of the equipment.

5. Anticipating the future costs that involves the operation, maintenance, repair, and replacement of equipment.

6. Identification of options that can be implemented for maximizing the efficiency of the building system.

7. Implementation of all the suitable possible measures to achieve the proposed goals.

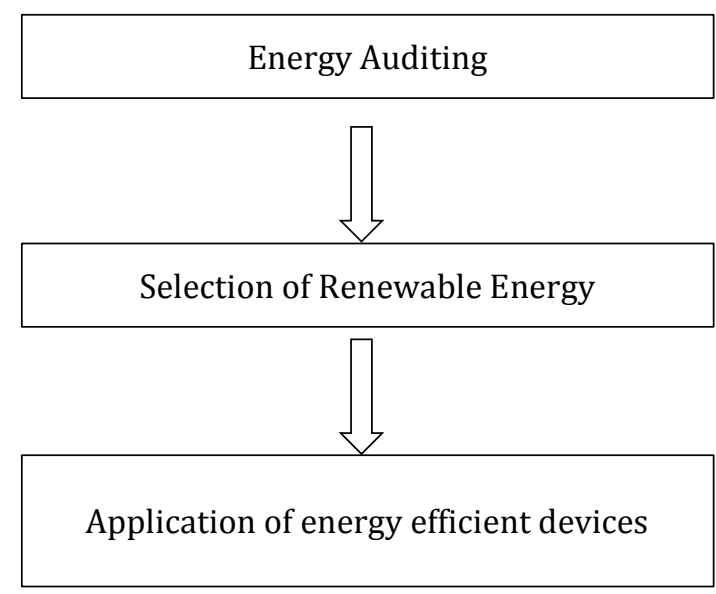

Fig.1 Flow chart representing the methodology

\subsection{Energy Audit}

Energy Audit, also known as energy assessment is the first way to have knowledge of the energy used by any organization or residential building. The energy audit of EPCO building was conducted which included the survey of existing loads in the office building and the collection of electricity bills of last 11 months.
The building comprised of a total of 40 rooms divided into various sections namely administrative section, planning section, SEIAA section, research section, account section, personal staff, computer section, library, conference room. The building also had a bank in its premises. The auditing also covered a separate section of Waste Paper Recycle Plant (WPR).

The figures depict the energy consumption by the various electrical and electronic equipments installed in the EPCO building.

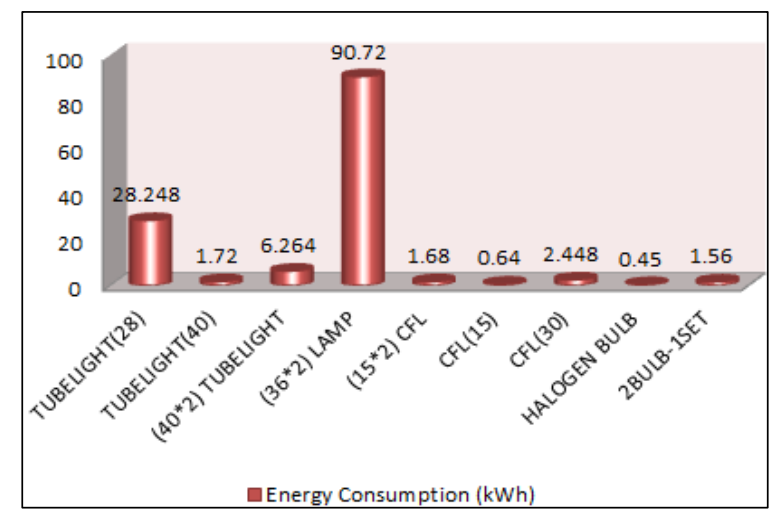

Fig.2 Energy consumption profile of lighting loads of the building

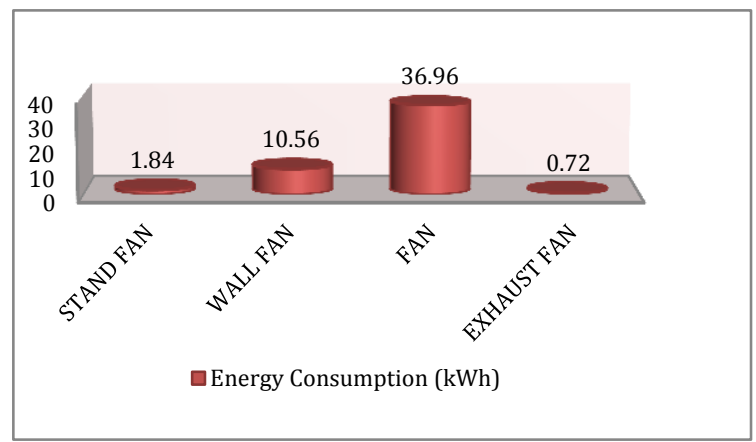

Fig.3 Energy consumption profile of fans of the building

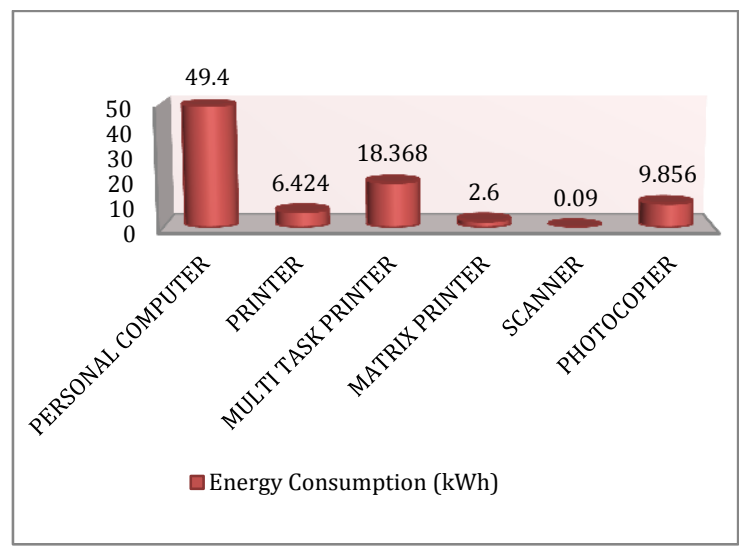

Fig.4 Energy consumption profile of computer and its peripherals of the building 


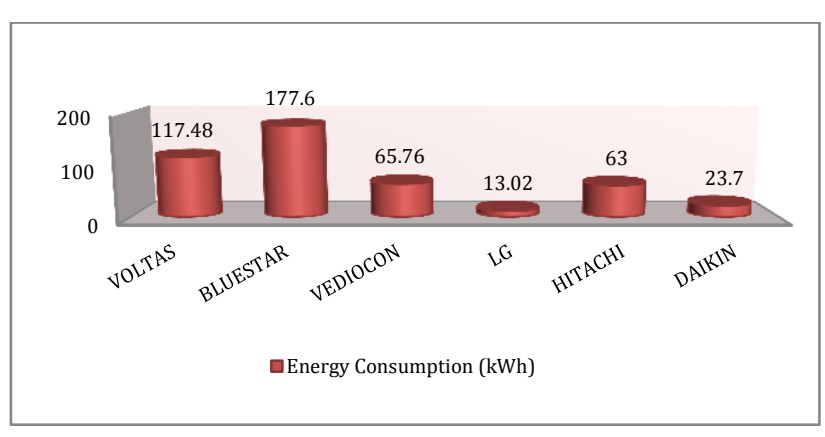

Fig.5 Energy consumption profile of air conditioning units of the building

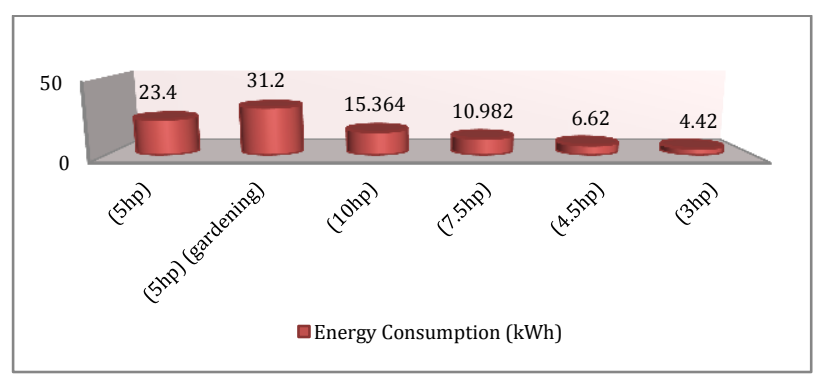

Fig.6 Energy consumption profile of pumps in the building

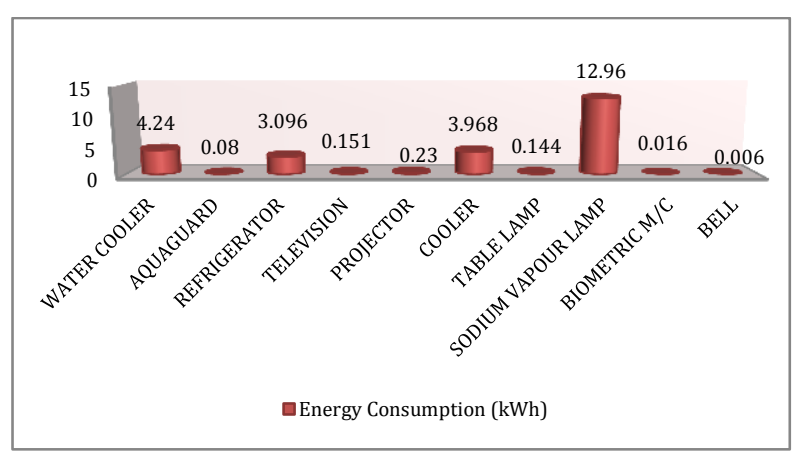

Fig.7 Energy consumption profile of miscellaneous loads of the building

\subsection{Energy Analysis of the building}

$\frac{\text { Load }}{\text { day }} k W=$ Rating of appliance $*$ No. of appliance

(Taking 24 working days in a month)

$$
\frac{\text { Load }}{\text { month }} k W=\left(\frac{\text { load }}{\text { day }}\right) * 24
$$

$\frac{\text { Power Consumed }}{\text { month }} k W h=($ Load $*$ operating hours $) * 24$

Table1 Power consumption details of the building

\begin{tabular}{|c|c|c|c|}
\hline Season & Load/day & Load/month & $\begin{array}{c}\text { Power } \\
\text { consumed/ } \\
\text { month }\end{array}$ \\
\hline Summer & $155.516 \mathrm{~kW}$ & $3732.384 \mathrm{~kW}$ & $20351.64 \mathrm{kWh}$ \\
\hline $\begin{array}{c}\text { Winter+ } \\
\text { Rainy }\end{array}$ & $83.197 \mathrm{~kW}$ & $1996.728 \mathrm{~kW}$ & $9202.97 \mathrm{kWh}$ \\
\hline
\end{tabular}

The use of air conditioners during the summer seasons results in the increased power consumption as compared to rest of the year.

\subsubsection{Analysis of Electricity Bills}

The EPCO campus is connected to the main supply of MPKVVCL by Bhadbhada substation, Bhopal.

The connection is a Non-Industrial Urban Feeder type.

Tariff type-HV3.2A, $11 \mathrm{kV}$ Supply

Contract Demand- 90kVA

Billing Demand- $81 \mathrm{kVA}$

Table 2 Electricity bill of EPCO building

\begin{tabular}{|c|c|c|c|c|c|c|c|c|c|c|c|}
\hline S.No. & Month & $\begin{array}{c}\text { Max } \\
\text { Demand } \\
(\mathrm{kVA})\end{array}$ & $\begin{array}{c}\text { Extra } \\
\text { Charged } \\
\text { Units } \\
(\mathrm{kVA}) \\
\end{array}$ & $\begin{array}{c}\text { Per } \\
\text { Unit } \\
\text { Charge } \\
\text { (Rs.) }\end{array}$ & $\begin{array}{l}\text { Units } \\
\text { Cons. } \\
(\mathrm{kWh})\end{array}$ & $\begin{array}{l}\text { Billing } \\
\text { Amount } \\
\text { (Rs.) }\end{array}$ & $\begin{array}{l}\text { Billing Of } \\
\text { Extra } \\
\text { Charged } \\
\text { Units(Rs.) }\end{array}$ & $\begin{array}{c}\text { Fixed } \\
\text { Charges } \\
\text { (Rs.) }\end{array}$ & $\begin{array}{l}\text { Power } \\
\text { Factor }\end{array}$ & $\begin{array}{c}\text { Power } \\
\text { Factor } \\
\text { Penalty } \\
\text { (Rs.) }\end{array}$ & $\begin{array}{c}\text { Total } \\
\text { Bill } \\
\text { (Rs.) }\end{array}$ \\
\hline 1 & Jan'16 & 25 & 56 & 6.05 & 5426 & 32827.3 & 14000 & 20250 & 0.76 & 7512.84 & 64614 \\
\hline 2 & Dec'15 & 39 & 42 & 6.05 & 5837 & 35313.85 & 10500 & 20250 & 0.78 & 6753.99 & 67307 \\
\hline 3 & Nov'15 & 52 & 29 & 6.05 & 8090 & 48944.5 & 7250 & 20250 & 0.85 & 2463.41 & 78660 \\
\hline 4 & Oct'15 & 51 & 30 & 6.05 & 8559 & 51781.95 & 7500 & 20250 & 0.9 & nil & 79620 \\
\hline 5 & Sept'15 & 49 & 32 & 6.05 & 8234 & 49815.7 & 8000 & 20250 & 0.9 & nil & 79898 \\
\hline 6 & Aug'15 & 61 & 20 & 6.05 & 16694 & 100998.7 & 5000 & 20250 & 0.91 & nil & 160717 \\
\hline 7 & July'15 & 48 & 33 & 6.05 & 7158 & 43305.9 & 8250 & 20250 & 0.84 & 3191.75 & 75107 \\
\hline 8 & June'15 & 48 & 33 & 6.05 & 10158 & 61455.9 & 8250 & 20250 & 0.88 & 1229.12 & 91403 \\
\hline 9 & May-15 & 65 & 16 & 5.5 & 9723 & 53476.5 & 3200 & 16200 & 0.87 & 1688.83 & 82101 \\
\hline 10 & April'15 & 47 & 34 & 5.5 & 6336 & 34848 & 6800 & 16200 & 0.83 & 3301.69 & 61004 \\
\hline 11 & March'15 & 32 & 49 & 5.5 & 5414 & 29777 & 9800 & 16200 & 0.81 & 4075.11 & 55717 \\
\hline
\end{tabular}




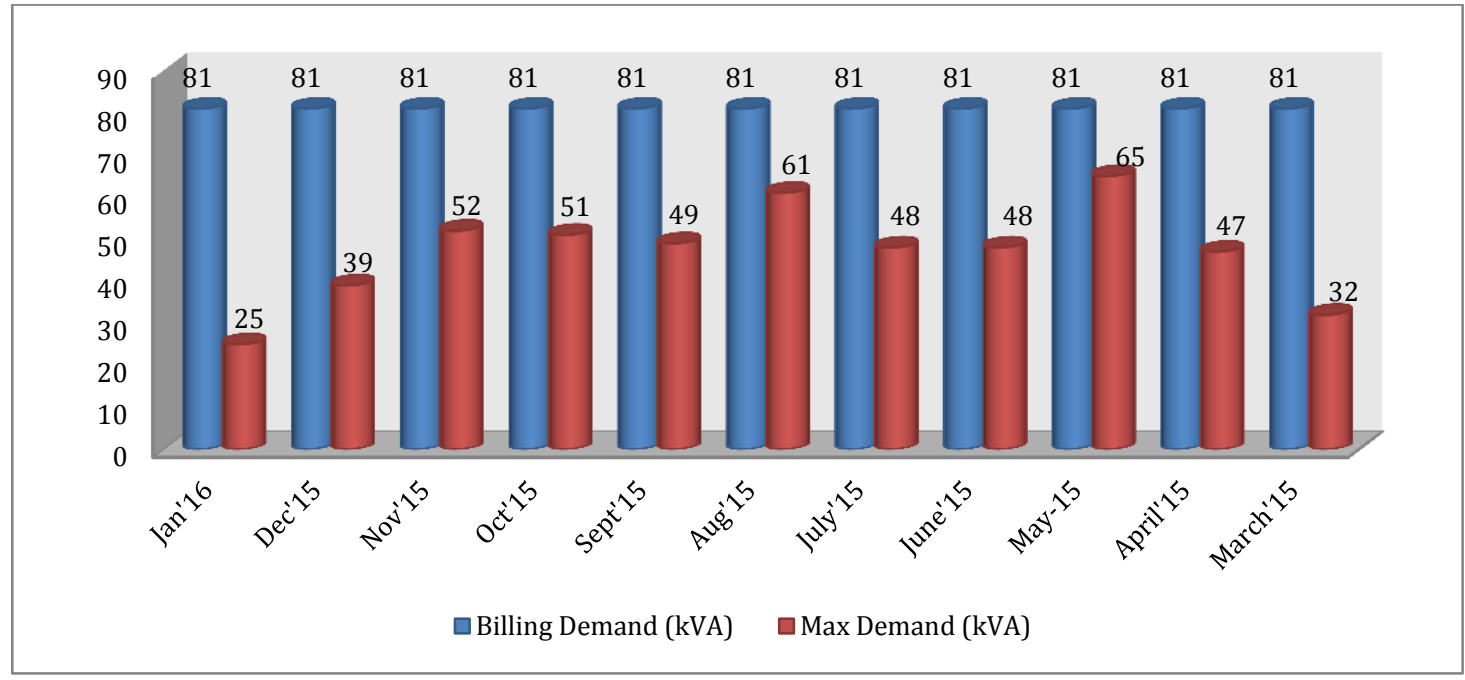

Fig.8 Graph depicting Maximum Demand and Billing Demand of the building

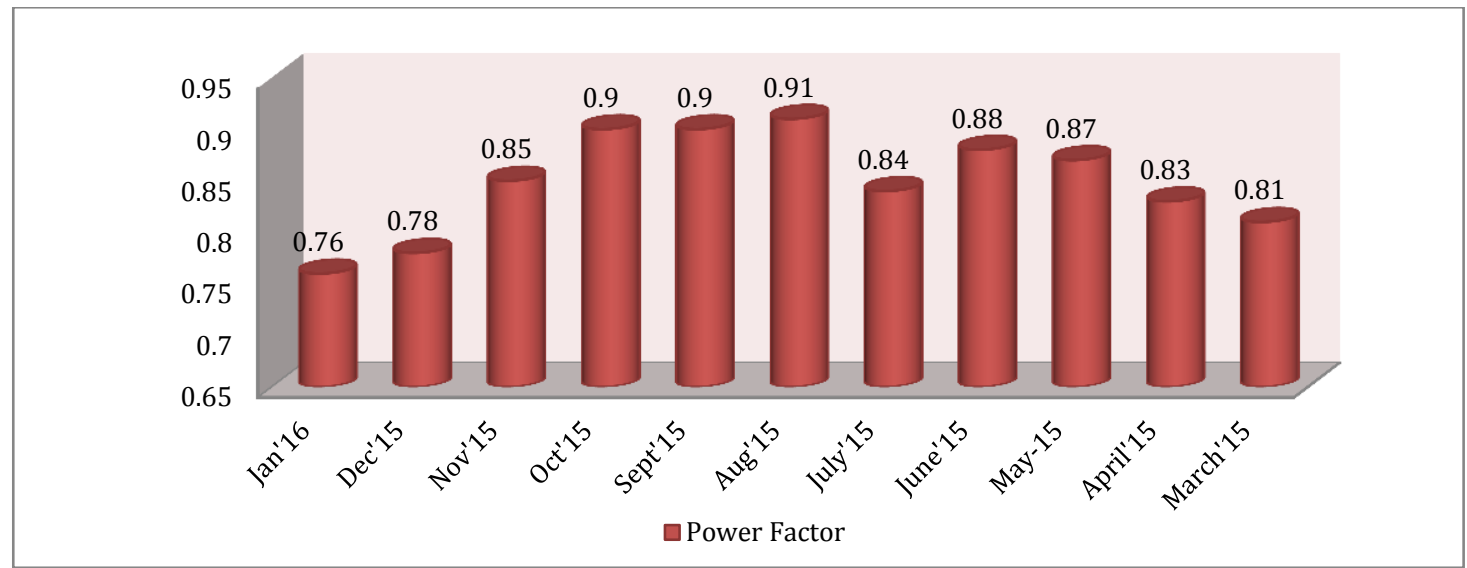

Fig.9 Graph depicting power factor of the building

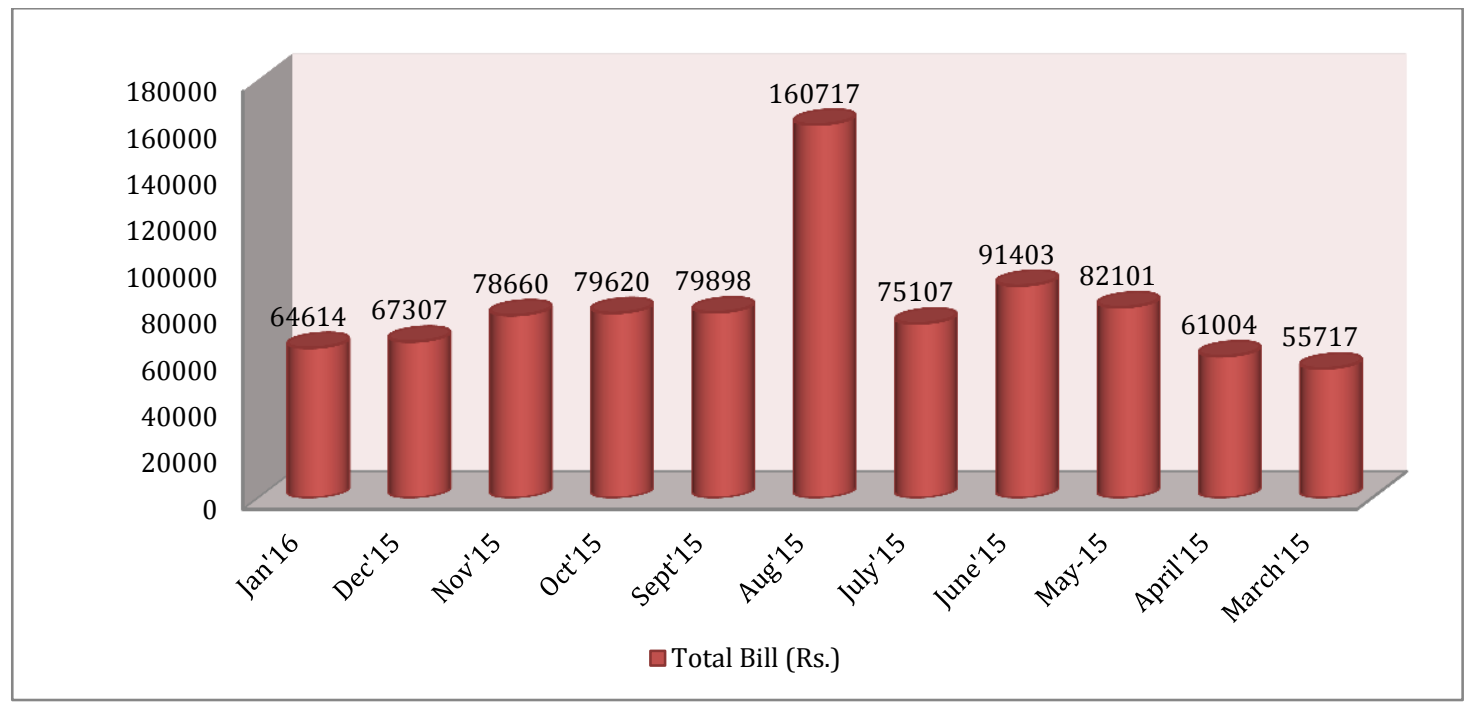

Fig.10 Graph depicting the total billing amount of electricity bill of the building

The analysis of the electricity bill of EPCO building shows that the power factor of the building is not maintained to 0.9 , which leads to the imposition of penalty. Also, there is a considerable difference in the billing demand and maximum demand. This causes the unnecessary payment of an amount in the bill. 
Thus, maintaining the power factor and modifying the billing demand will significantly bring down the total amount to be paid in a month.

\subsection{Selection of Energy Source}

The sources of renewable energy available near the EPCO campus are biomass, lake water, wind and the solar energy. The availability of biomass at a constant rate is not necessary, thus fails to prove its viability at the site. The use of lake water for generation is not feasible as setting up of the hydel plant near the residential sector is not permitted. The wind mills cannot be installed as no hilly terrain exists in the campus also the residential sector cannot be used for wind mill installation. The availability of solar energy is unconditional and thus a reliable source of power generation. The terrace of EPCO building spreads over an area of approximately $1750 \mathrm{~m}^{2}$. The effective area that could be utilized for solar panel installation is nearly $500 \mathrm{~m}^{2}$. The power that could be generated through solar energy is estimated to be $50 \mathrm{~kW}_{\mathrm{p}}$. Since the power can be generated on site thus Net Zero Site Energy Building proves to be the optimum choice of selection amongst the other types of net zero energybuilding. The generation of power at the site reduces the transmission losses and various other costing parameters like installation of cables for transmission, erection of poles etc.

\subsection{Building Design and Equipment Performance}

The design of EPCO building utilizes the natural resources efficiently. The designing is such that in winters the solar radiations incident in the rooms maintains the temperature of the room. In summers, the garden spreading all around the building circulates the cold breeze into the rooms. The construction allows the natural circulation of air throughout the building. Thus, no change in the designing of the building is required.
Some installed equipments in the building are not energy efficient and thus requires replacement. The performance of equipments is not proper which affects the total energy consumption of the building.

\subsection{Techno-Economic Analysis}

The performance of the equipments is defined by its efficiency in working. The inefficient equipments should be replaced by the technologically advanced equipments. The advanced technology equipments have high initial cost but are more durable and more efficient than the conventional fittings. The life cycle of these equipments is more than the conventional fittings thus prove their worth of installation.

3.5.1 Economic Analysis (Ganandran, Mahlia et al. 2014)

Annual Energy Savings $=$

Power consumption by (conventional -

technology advanced)fittings *

no. of operating hours $* 365$

Saving in electricity bill = Annual energy savings * cost of unit energy

Saving towards maintenance $=$

No. of conventional fittings $*$ maintenance cost

Taking maintenance cost=600Rs. $/$ year

Investment for technology advanced fittings $=$ No. of fittings $*$ cost of product

Payback period $=$ Investment for technology advanced fittings Total Savings

Table 3 Economic analysis of energy efficient equipments

\begin{tabular}{|c|c|c|c|c|c|c|c|c|c|}
\hline$\sum_{\dot{0}}^{\dot{0}}$ & 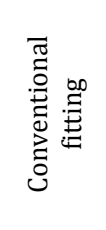 & 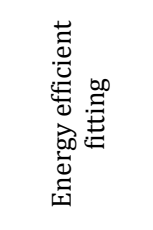 & 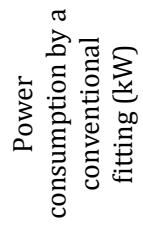 & 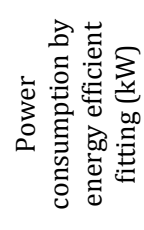 & 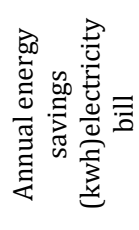 & 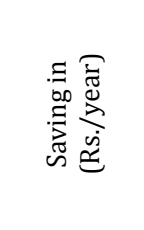 & 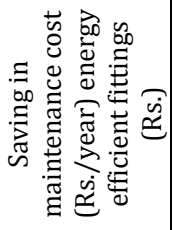 & 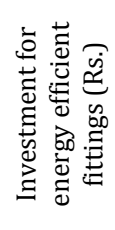 & 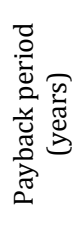 \\
\hline 1 & $\begin{array}{l}(36 * 2) \\
\text { lamps }\end{array}$ & $\begin{array}{c}\text { 18W LED } \\
\text { panel lights }\end{array}$ & 11.34 & 2.268 & 20901.88 & 126456.42 & 75600 & 252000 & 1.24 \\
\hline 2 & $\begin{array}{l}\text { Ceiling } \\
\text { Fans }\end{array}$ & $\begin{array}{c}\text { 35W } \\
\text { super- } \\
\text { efficient } \\
\text { fans }\end{array}$ & 4.62 & 2.1 & 5806.08 & 35126.784 & 36000 & 162000 & 2.27 \\
\hline 3 & $\begin{array}{l}40 \mathrm{~W} \\
\text { Tube } \\
\text { lights }\end{array}$ & $\begin{array}{l}\text { 18W LED } \\
\text { tubes }\end{array}$ & 0.602 & 0.252 & 806.4 & 4878.72 & 8400 & 25200 & 1.89 \\
\hline 4 & $\begin{array}{l}\text { Sodium } \\
\text { vapour } \\
\text { lamps }\end{array}$ & 90W LED & 1.08 & 0.54 & 2365.2 & 14309.46 & 3600 & 4800 & 0.26 \\
\hline
\end{tabular}




\subsubsection{Technical Analysis}

The replacement of inefficient fittings should be done on the basis of star ratings of the equipments.

\subsubsection{Replacement of $\left(36^{*} 2\right)$ by LED Panel Light}

The (36*2) lamps in the building consume about $90 \mathrm{~W}$ of energy. The total number of such lamps is around 126. The lamps could be replaced by the $18 \mathrm{~W}$ LED panel lights. Replacing these lamps could save $80 \%$ of current energy consumption by lamps.

\subsubsection{Replacement of Ceiling fans by Energy Efficient} fans

The power consumption of conventional ceiling fans is about 77W.There are total 60 ceiling fans. The fans could be replaced by the 5 -star, $35 \mathrm{~W}$ super-efficient fans. Replacing them with energy efficient fans will minimize the power consumption by $55 \%$.

\subsubsection{Replacement of 40W Tube lights by LED tubes}

The conventional tube lights consume about 43W of energy. The total number of tube lights is 14 , resulting in a large amount of energy wastage. Replacing these tube lights with 18W LED tubes would save $58 \%$ of energy.

\subsubsection{Replacement of Sodium Vapour Lamp by LED}

The sodium vapour lamps used for street lighting consumes $180 \mathrm{~W}$ of power. These should be replaced by the LED fixtures to save $50 \%$ of energy used by sodium vapour lamps. The $90 \mathrm{~W}$ LED fixtures could be installed in place of these lamps.

\section{Conclusion}

The energy audit and analysis of electricity bill indicated the areas of improvement necessary for transforming the building into a net-zero energy building. The replacement of equipments with energy saver equipments would significantly help in monetary savings. The application of power factor correction capacitors would maintain the power factor thus avoiding the penalty. Also, the installation of the solar photovoltaic system would considerably reduce the requirement of supply from the grid.

\section{References}

Mukherjee,S.(2011, May). Opportunities and challenges with net zero energy buildings. IEEE 23rd International Sym(Samarji, Jouni et al. 2012)posium on Power Semiconductor Devices and ICs (pp. 1-5).

Torcellini, P., Pless, S., \& Leach, M. (2015). A pathway for netzero energy buildings: creating a case for zero cost increase. Building Research \& Information, 43(1), 25-33.

Kapoor, R., Deshmukh, A., \& Lai, S. (2011). Strategy roadmap for net zero energy buildings in India. USAID India, http://eco3. org/wp-content/plugins/downloadsmanager/upload/NZEBpercent20Roadmap-2 percent20Sept percent, 20, 2011.

General Aspects of Energy management and Energy audit, Energy efficiency in electrical utilities, Bureau of energy efficiency,chapter3, https://beeindia.gov.in/sites/default/files/1Ch3.pdf

Ganandran, G. S. B., Mahlia, T. M. I., Ong, H. C., Rismanchi, B., \& Chong, W. T. (2014). Cost-Benefit Analysis and Emission Reduction of Energy Efficient Lighting at the Universiti Tenaga Nasional. The Scientific World Journal, 2014.

Darko, E., Nagrath, K., Niaizi, Z., Scott, A., Varsha, D., \& Vijaya, K. (2013). Green building: case study.

http://www.energy.gov/public-services/homes/homeweatherization/home-energy-audits

http://www.nzeb.in/definitions-policies/definitions/

https://www.energysavings.com/energy-consumption.html 